\title{
Designing a Bill of Rights for Northern Ireland
}

\author{
Colin Harvey and Alex Schwartz* \\ Queen's University Belfast
}

\begin{abstract}
Introduction
$\mathrm{T}$ This special issue of the Northern Ireland Legal Quarterly is dedicated to Professor Tom Hadden. Professor Hadden has been involved in the debate on a Bill of Rights for Northern Ireland over an extended period. He combines both keen scholarly interest with dedicated practical engagement, the latter being demonstrated by his membership on the Standing Advisory Commission on Human Rights (SACHR) and, later, the Northern Ireland Human Rights Commission from 1999-2005. He has put his scholarly resources to use in public life through his efforts to guide the debate on a Bill of Rights. ${ }^{1}$ This article is written with the example of Professor Hadden's consummate scholarly work, animated as it is by practical concerns, firmly in mind.

The aim here is to examine the Bill of Rights process in Northern Ireland and unearth lessons that might be derived from it. In order to address this question, three themes are dealt with: first, the history of the process; second, the role of the Northern Ireland Human Rights Commission; and third, debates on rights relating to culture and identity. Our argument is that any Bill of Rights must be reflective of international standards and pay attention to the particular circumstances of the society within which it will operate if it is to gain recognition and acceptance. The Northern Ireland experience is an example of how this has been attempted in a society seeking to emerge from violent conflict. Ultimately, we offer some arguments as to how the circumstances of Northern Ireland (specifically, ethnonational division) ought to inform the substance of its Bill of Rights.
\end{abstract}

* Professor Colin Harvey is Head of the School of Law at Queen's University Belfast. He is also a commissioner on the Northern Ireland Human Rights Commission. This article is written in a personal capacity only. Alex Schwartz is currently a PhD candidate at the School of Law, Queen's University Belfast.

1 See e.g. K Boyle and T Hadden, Northern Ireland: The Choice (London: Penguin Books 1994), pp. 181-6; K Boyle and T Hadden, Ireland: A positive proposal (Harmondsworth: Penguin Books 1985), pp. 80-3; K Boyle, T Hadden and P Hillyard, Law and State: The case of Northern Ireland (London: Martin Robertson 1975), note that Chapter 2 of this book is entitled "Civil rights: the failure of law and of lawyers". See also T Hadden and E Craig, Integration and Separation: Rights in divided societies (Belfast: Fortnight Educational Trust 2000). 


\section{History of the Bill of Rights process}

The idea of a Bill of Rights for Northern Ireland predates the Belfast (Good Friday) Agreement by over 30 years. $^{2}$ The evolution of that idea can be divided into two distinct phases: the pre-Agreement phase and the post-Agreement phase. As we shall see, the content of the proposals for the Bill of Rights differs considerably between these two phases. In the first phase, proposals were generally focused on the classic liberal package of individual equality, civil liberties, and due process rights. In a few cases, these proposals also included rights to proportional representation in Northern Ireland's legislature as part of a political settlement to the conflict. ${ }^{3}$ Generally speaking, however, the first phase of proposals was targeted at redressing the legacy of religious and political discrimination in Northern Ireland and the extraordinary measures employed by the state to combat paramilitary violence. By the time of the Agreement in 1998, however, these concerns were being addressed (or would soon be) through other mechanisms, either via ordinary equality legislation or the enactment of the Human Rights Act $1998 .{ }^{4}$ Not surprisingly then, proposals for the Bill of Rights in the post-Agreement phase have broadened in scope to include not only classic liberal human rights, but also socio-economic rights. In addition, proposals in the second phase have drawn upon the Agreement's references to principles of "parity of esteem" and "mutual respect for the identity and ethos of both communities", identifying these as values that ought to be reflected in a Bill of Rights for Northern Ireland. ${ }^{5}$ Furthermore, the burgeoning development of international minority rights norms, in particular the Council of Europe's Framework Convention for the Protection of National Minorities, has provided a new source of discussion.

\section{THE PRE-AGREEMENT PHASE}

The first concrete proposals for a human rights instrument particular to Northern Ireland came from Shelagh Murnaghan, a member of the Stormont Parliament, who proposed a Human Rights Bill on 27 May 1964. ${ }^{6}$ The Bill would have made it an offence to discriminate against any person "on the grounds of race, creed, colour or political belief", and it would have established a Human Rights Commission to investigate allegations of discrimination. That Bill was defeated on its second reading by a vote of 17 to $23 .^{7}$ Later, a separate proposal for a Bill of Rights for Northern Ireland was presented at Westminster to both the House of Lords and the Commons on 12 May 1971 by Lord Brockway and Arthur Latham MP, respectively. ${ }^{8}$ In this proposal, the idea of a Bill of Rights was linked to broader reforms geared towards achieving a political settlement to the conflict in Northern Ireland, a link that would persist throughout many of the subsequent proposals, including the Belfast (Good Friday) Agreement in 1998.9 The original Bill proposed five elements for reform: (1) the prohibition of discrimination on the ground of religion; (2) the right to advocate peacefully for a united Ireland and a prohibition of oaths of allegiance;

2 The first concrete proposals for a Human Rights Bill came in 1964 (see n. 6 below).

3 See nn. 6 and 21 below.

4 For an overview of Northern Ireland equality legislation see C McCrudden, "Equality", in C Harvey (ed.) Human Rights, Equality and Democratic Renewal in Northern Ireland (Oxford: Hart Publishing 2001). The Human Rights Act 1998 came into force on 2 October 2000.

5 Agreement reached in multiparty talks (The Agreement), "Rights, safeguards and equality of opportunity", para. 4.

6 See Northern Ireland Parl. Debs, 27 May 1964, vol. 57, p. 1296.

7 See Northern Ireland Parl. Debs, 16 June 1964, vol. 57, p. 1989.

8 Hansard HC Debs, 12 May 1971, vol. 817, cc. 383-94; HL Debs, 12 May 1971, vol. 318, c. 1067.

9 The Agreement, "Rights, safeguards and equality of opportunity", para. 4. 
(3) proportional representation in public authorities; (4) due process rights and the repeal of emergency powers (especially the Special Powers Act); and (5) "that discussions should be authorised between Northern and Southern Ireland". ${ }^{10}$ Although the Bill passed its first reading at the Lords, it was defeated by a Tory three-line whip at the House of Commons and, on 15 June 1971, it was defeated in the Lords on its second reading. ${ }^{11}$

Despite early floundering, the idea of a Bill of Rights for Northern Ireland proved to be both resilient and contagious. This was especially the case in left-wing circles, where the campaign for a Bill of Rights was continued by the Northern Ireland Civil Rights Association (NICRA). NICRA would go on to publish its own draft proposal for a Bill of Rights for Northern Ireland in $1975 .{ }^{12}$ But the idea proved to be a popular one in more "mainstream" circles as well. The Northern Ireland Office published a discussion paper in 1972, The Future of Northern Ireland - A Paper for discussion, in which it expressed qualified support for a Bill of Rights for Northern Ireland. ${ }^{13}$

Following up on the discussion paper, the Northern Ireland Office returned to the idea of a Bill of Rights in its 1973 report to Parliament, Northern Ireland Constitutional Proposals. ${ }^{14}$ The report envisaged a "Charter of Human Rights" as part of a comprehensive package of reforms, most of which would later be enacted in the Northern Ireland Constitution Act 1973. ${ }^{15}$ Significantly, the report lacked proposals for due process rights and the repeal of emergency powers, focusing instead on issues of equality and discrimination. ${ }^{16}$ Specifically, the 1973 report proposed legislative provisions that would prohibit religious or political discrimination in both the use of the assembly's law-making powers and in the use of executive power. ${ }^{17}$ The courts would be given the power to strike down any offending legislation or executive action as ultra vires and to grant a range of legal remedies. ${ }^{18}$

Proposals for a Bill of Rights for Northern Ireland continued throughout the 1970s. A committee chaired by Lord Gardiner (the "Gardiner Committee"), was tasked to consider "in the context of civil liberties and human rights, measures to deal with terrorism in Northern Ireland". 19 Although beyond its specific mandate, the Gardiner Committee's report in January 1975 recommended that "[c]onsideration should be given to the enactment of a Bill of Rights" as part of a general political solution to the conflict in Northern Ireland. ${ }^{20}$

In April 1975, NICRA followed up with its own draft proposals for a Bill of Rights. ${ }^{21}$ These drew extensively from the International Covenant on Civil and Political Rights

10 HL Bill 157 1970/71. See Hansard HL Debs, 15 June 1971, vol. 320, cc. 538-75, at 539.

11 Hansard HL Debs, 15 June 1971, vol. 320, cc. 538-75. Lord Brockway attempted to reintroduce a partially amended Bill on 23 June 1972, this time limited to the repeal of emergency powers, the prohibition of discrimination on the grounds of religion, the right to advocate peacefully for a united Ireland, and the prohibition of oaths of allegiance. Lord Brockway withdrew his motion, however, after debate persuaded him that the timing was inappropriate. See Hansard HL Debs, 23 June 1972, vol. 332, cc. 531-57, at 557.

12 Northern Ireland Civil Rights Association, Bill of Rights (Northern Ireland) Act 1975 (Belfast: NICRA, 1975).

13 Northern Ireland Office, The Future of Northern Ireland - A paper for discussion (London: HMSO 1972).

14 Northern Ireland Office, Northern Ireland Constitutional Proposals (London: HMSO 1973).

15 See Northern Ireland Constitution Act 1973.

16 Northern Ireland Office, Northern Ireland Constitutional Proposals, n. 14 above, p. 24, para. 91.

17 Ibid. p. 25, para. 95.

18 Ibid. p. 25, paras. 95-6.

19 See Report of a Committee to Consider, in the Context of Civil Liberties and Human Rights, Measures to Deal with Terrorism in Northern Ireland (London: HMSO 1975).

20 Ibid. para. 21.

21 See n. 12 above. 
(ICCPR), which the United Kingdom had signed on 16 September 1968, but did not ratify until 20 May 1976. Several provisions were also more tailored to political disagreement in Northern Ireland. These entailed rights to political expression, including rights to propagate, associate, or advocate for either maintaining Northern Ireland as an integral part of the United Kingdom or for the "establishment of a single parliament for the whole of Ireland", the right to propagate or advocate "republican" and "loyalist" opinion, as was well as the right to "display flags or emblems of any country in friendly relations with the United Kingdom". 22 In addition, the draft Bill prohibited the requirement of oaths of allegiance that might offend the conscience of anyone who wished to maintain Northern Ireland as part of the United Kingdom, establish "a single parliament for the whole of Ireland", or advocate one or more sovereign parliaments for Northern Ireland "independent of Westminster". ${ }^{23}$

Not long after NICRA's draft Bill was published, the idea of a Bill of Rights for Northern Ireland was the subject of debate in the Constitutional Convention of 1975, where representatives from Northern Ireland's political parties (excluding Sinn Fein) convened to discuss possible options for a political settlement to the conflict. ${ }^{24}$ There, the main unionist parties (who had previously grouped together as the United Ulster Unionist Council to oppose the Sunningdale Agreement) proposed "a general Bill of Rights and Duties to protect the rights of the individual citizen". ${ }^{25}$ The Social Democratic and Labour Party (SDLP) proposed that the European Convention on Human Rights (ECHR) be incorporated into the domestic law of Northern Ireland and that Part III of the Northern Ireland Constitution Act 1973, which outlaws religious and political discrimination, should be retained. ${ }^{26}$ The Alliance Party proposed a Bill of Rights based on the Universal Declaration of Human Rights. ${ }^{27}$ The Northern Ireland Labour Party preferred that there be a uniform bill of rights throughout the United Kingdom as "an essential badge of common citizenship". ${ }^{28}$ Brian Faulkner's Unionist Party of Northern Ireland preferred that human rights legislation be enacted locally by the Northern Ireland legislature. ${ }^{29}$

Subsequently, SACHR went on to publish a discussion paper in March 1976. ${ }^{30}$ The discussion paper outlined various issues for consideration concerning the scope and application of a Bill of Rights, including the sufficiency of existing protections under domestic law and the ECHR, whether the Bill should apply across the entire United Kingdom or be limited to Northern Ireland, whether or not it could bind Westminster, and whether or not the Bill should be entrenched against regular legislative amendment. ${ }^{31}$ The discussion paper also flagged the issue of whether or not there should be a special court tasked with enforcing the Bill of Rights. ${ }^{32}$ The paper invited submissions to the Commission on these questions.

Meanwhile, the apparent consensus in favour of a Bill of Rights for Northern Ireland expressed at the Constitutional Convention inspired Lord Brockway to introduce a new

22 Report of a Committee, n. 19 above, p. 9, cl. 9(1).

23 Ibid. p. 9, cl. 9(2).

24 See Northern Ireland Constitutional Convention, Report (London: HMSO, 20 November 1975).

25 Ibid. para. 124.

26 Ibid. para. 129.

27 Ibid.

28 Ibid.

29 Ibid.

30 SACHR, Bill of Rights: A discussion paper (Belfast: HMSO, 5 March 1976).

31 Ibid. pp. 13-15.

32 Ibid. p. 15. 
draft Bill at the House of Lords in February 1976, drawing in part upon NICRA's draft Bill of Rights of $1975 .{ }^{33}$ Lord Brockway subsequently withdrew his motion for a second reading that March, in light of the fact that Lord Wade had already presented a draft Bill that would apply to the entire United Kingdom and because SACHR was in the process of taking evidence with a view to a full report on a Bill of Rights for Northern Ireland. ${ }^{34}$ Prior to SACHR's report, however, Lord Brockway presented a revised Bill of Rights on 1 March 1977. ${ }^{35}$ His purpose this time was to generate discussion of his proposals. Following the lead of earlier proposals from the SDLP, this Bill marked the beginning of a new impetus to incorporate the ECHR into the law of Northern Ireland. It also took up NICRA's proposal for a special constitutional court that would sit as a panel of five judges. In addition, the Bill provided for derogations in a state of emergency where "the United Kingdom Parliament, or, eventually, a Stormont Parliament, so decided by a three-quarters majority". 36 Lord Brockway withdrew his motion for a second reading on 26 May 1977, after he was satisfied he had generated the desired debate. ${ }^{37}$

When SACHR's report was eventually published in November 1977, it marked a definite change in approach to the idea of a Bill of Rights for Northern Ireland. ${ }^{38}$ First, the report noted that the "consensus on the need for a Bill of Rights expressed in the Report of the Northern Ireland Constitutional Convention was more apparent than real".39 As it explained, an "[e]xamination of the various views expressed by those supporting a Bill of Rights in fact revealed a variety of different approaches and emphases, particularly in relation to the scope and character of the rights and freedoms to be guaranteed and the means by which a Bill of Rights should be enforced". ${ }^{40}$ Nevertheless, according to the report, there was a "substantial majority" who favoured the introduction of a Bill of Rights for the entire United Kingdom, as opposed to one limited to Northern Ireland. ${ }^{41}$ It noted, for example, that while the SDLP preferred a Bill of Rights as part of an overall constitutional settlement package, it had also accepted the idea of a UK-wide Bill as a viable alternative. ${ }^{42}$ The view of many others, however, was that it was "unjustifiable to treat Northern Ireland as a separate part of the United Kingdom requiring a separate Bill of Rights". 43

The report went on to say that "a substantial body of opinion favoured the incorporation of the European Convention on Human Rights" into the legal system, preferably on a UK-wide level, to be enforced directly by the courts. ${ }^{44}$ This was seen to be more practical from both a legal and a political perspective than the alternative of a freestanding Bill of Rights, particularly in the absence of a devolved government. ${ }^{45}$ The report did note, however, that, in the event of the restoration of a devolved government, the enabling legislation ought to include "a clear and enforceable Charter of Rights for Northern Ireland", more comprehensive than the ECHR and "framed in the light of

33 Hansard HL Debs, 26 February 1976, vol. 368, c. 816.

34 Hansard HL Debs, 25 March 1976, vol. 369, cc. 818-39.

35 Hansard HL Debs, 1 March 1977, vol. 380, c. 502.

36 Ibid.

37 Hansard HL Debs, 26 May 1977, vol. 383, cc. 1428-60.

38 SACHR, The Protection of Human Rights by Law in Northern Ireland (Belfast: HMSO November 1977).

39 Ibid. p. 25, para. 4.04

40 Ibid. p. 25, para. 4.05 .

41 Ibid. p. 25, para. 4.07.

42 Ibid.

43 Ibid.

44 Ibid. p. 26.

45 Ibid. p. 28, para. 4.17. 
whatever at the time seem to be the special needs of the people of Northern Ireland". 46 The report also flagged the clarification and codification of police powers, as well as reforms in administrative law to increase the rights and freedoms of individuals in relation to public authorities, as two possible areas for further rights-based reforms. ${ }^{47}$

Following SACHR's report, subsequent proposals for a Bill of Rights in Northern Ireland throughout the late 1970s and 1980s were generally supplanted by, or subsumed under, the campaign for a Bill of Rights for the United Kingdom as a whole (a detailed account of the wider campaign for a United Kingdom Bill of Rights is beyond the scope of the present discussion). ${ }^{48}$ This is not to say that the idea of a Bill of Rights specific to Northern Ireland dropped off the map altogether. The idea was periodically raised in the Commons and the House of Lords throughout the 1980s and early 1990s. ${ }^{49}$ SACHR, in its 1990 report on religious and political discrimination, also suggested adopting "legislative or constitutional measures to recognise and accommodate the rights and identities of the two major sections of the community, and possibly other minority groups". ${ }^{50}$ In addition, the Committee on the Administration of Justice (a Northern Ireland human rights NGO) continued to campaign for a Bill of Rights for Northern Ireland, eventually publishing its own draft in May 1993. ${ }^{51}$ Nevertheless, the Northern Ireland Office ceased to pursue any concrete proposals during the 1980s and the issue received only a passing reference in the Anglo-Irish Agreement of 1985. 52

\section{THE POST-AGREEMENT PHASE}

The idea of a Bill of Rights for Northern Ireland began to gain momentum again in the multiparty talks leading up to the Belfast (Good Friday) Agreement. Indeed, at one time or another representatives of every major political party in Northern Ireland have expressed support for the idea of a Bill of Rights for Northern Ireland. ${ }^{53}$ Following on from their earlier work, it was also a key element of Professor Hadden's and Professor Kevin Boyle's suggestions for reform in their influential book, Northern Ireland: The Choice, published in 1994. ${ }^{54}$ Again, as we shall see, this apparent consensus masked several sharp points of disagreement on content. All the same, the political climate in the late 1990s was right for a return to the idea of a Bill of Rights as part of a durable and comprehensive constitutional settlement.

46 SACHR, The Protection, n. 38 above, p. 76, para. 10.

47 Ibid. p. 76, para. 15.

48 For a recent overview of the debate see Joint Committee on Human Rights, "Twenty-ninth Report: A Bill of Rights for the UK?"(10 August 2008) HL 165-I/HC 150-I; see also M Zander, A Bill of Rights? 4th edn (London: Sweet \& Maxwell, 1997).

49 See Hansard HC Debs, 6 May 1980, vol. 984, c. 43W; HC Debs, 25 March 1982, vol. 20, c. 1083; HL Debs, 28 October 1986, vol. 481, cc. 606-8; HC Debs, 10 March 1988, vol. 129, cc. 521-33; HC Debs, 22 June 1989 , vol. 155, cc. 479-81; HC Debs, 7 November 1991, vol. 198, c. 232W; HC Debs, 29 October 1992, vol. 212, cc. 1119-20; HC Debs, 17 February 1994, vol. 237, c. 990W; HC Debs, 27 October 1994, vol. 248, c. 787W; HC Debs, 24 October 1994, vol. 248, c. 452W; HC Debs, 11 July 1996, vol. 281, c. 313W.

50 See SACHR, Second Report: Religious and political discrimination and equality of opportunity in Northern Ireland (Belfast: HMSO March 1990), p. 89.

51 Committee on the Administration of Justice, A Bill of Rights for Northern Ireland (Belfast: CAJ May 1993).

52 Anglo-Irish Agreement 1985, Article 5(a), available at http://cain.ulst.ac.uk/events/aia/aiadoc.htm.

53 See Committee on the Administration of Justice, A Bill of Rights for Northern Ireland through the Years - The views of the political parties (Belfast: CAJ July 2003).

54 Boyle and Hadden, Northern Ireland: The Choice, n. 1 above. The suggestion is also made in Ireland: A positive proposal, n. 1 above, p. 83: "These various protections would be given greater force if they were incorporated in a general Bill of Rights for Northern Ireland covering both individual and communal rights . . . Specific reference to the need for such a Bill of Rights ... should be incorporated in the proposed Anglo-Irish Treaty, as should appropriate provisions for the joint monitoring of performance." 
The Agreement provided for the establishment of the Northern Ireland Human Rights Commission, which was to replace SACHR and "advise on the scope for defining, in Westminster legislation" a Bill of Rights for Northern Ireland. ${ }^{55}$ Following the Agreement, the Human Rights Commission was established under the Northern Ireland Act 1998.56 The Commission began its work on the Bill of Rights in 2000. On 1 March 2000, the Human Rights Commission launched a series of outreach measures in an effort to raise awareness and promote discussion of the proposed Bill of Rights. These efforts included training and education, promotional pamphlets, and consultations with political parties, NGOs, women's groups, and children and young people. ${ }^{57}$ The Commission also established nine advisory working groups to produce reports to the Commission on different areas of rights. The areas covered by the working groups were: Children and Young People; Criminal Justice; Culture and Identity; Education; Equality; Implementation Issues; Language, Social and Economic Rights; and Victims' Rights. ${ }^{58}$ Over the next two years, the Commission would receive over 600 written submissions from political parties and non-governmental/civil society organisations. ${ }^{59}$

In September 2001, the Human Rights Commission published its preliminary views in a document entitled Making a Bill of Rights for Northern Ireland. ${ }^{60}$ It included draft clauses on democratic rights; "rights concerning identity and communities"; equality/nondiscrimination; women's rights; rights to life; freedom from torture, inhuman or degrading punishment; freedom from slavery and forced labour; due process rights; rights of victims; rights to family and private life; rights of children; educational rights; rights to freedom of thought, expression, information, and association; language rights; and socio-economic and environmental rights.

The consultation document quickly attracted criticism from NGOs and political parties from both sides of the communal divide. ${ }^{61}$ The two nationalist parties argued that the Commission had adopted an overly individualistic approach to human rights at the expense of guaranteeing parity of esteem for the two main communities. ${ }^{62}$ Along with the nationalist parties, the Equality Commission was also concerned that the proposals might even undermine existing equality protections. ${ }^{63}$ Others argued that the Commission had exceeded its mandate by including proposals for rights that went beyond "the particular circumstances of Northern Ireland". ${ }^{64}$ Still others argued that the Commission had failed to have sufficient regard for international norms and (consequently) had not gone far enough towards addressing the concerns of disadvantaged groups. ${ }^{65}$ The Commission's

55 The Agreement, "Rights, safeguards and equality of opportunity", para. 4.

56 Northern Ireland Act 1998, s. 68.

57 See Northern Ireland Human Rights Commission, Taking Forward a Bill of Rights for Northern Ireland (Belfast: NIHRC February 2005), pp. 8-11.

58 Ibid., p. 8 .

59 See Northern Ireland Human Rights Commission, Summary of Submissions on a Bill of Rights (Belfast: NIHRC July 2003).

60 Northern Ireland Human Rights Commission, Making a Bill of Rights for Northern Ireland (Belfast: NIHRC September 2001).

61 See Northern Ireland Human Rights Commission, Progressing a Bill of Rights: An update (Belfast: NIHRC April 2004), pp. 8-9.

62 See Sinn Fein, "Submission” 269, http://www.borini.info/submissions/submission_269.pdf; and SDLP, "Submission" 217, http://www.borini.info/submissions/submission_217.pdf.

63 The concern here was that the proposed right not to be treated as a member of a particular community might threaten aspects of equality legislation that require monitoring of communal background. See Equality Commission, "Submission" 343, p. 7, http://www.borini.info/submissions/submission_343.pdf.

64 For an overview of these criticisms, see Progressing a Bill of Rights (n. 61 above), p. 9.

65 Ibid. 
first draft also attracted academic criticisms. ${ }^{66}$ Professor McCrudden described the proposals as "woefully under-theorized in the post-Good Friday Agreement context".67 One of McCrudden's key criticisms was that the Commission had failed to explain how its proposals related (or not) to the circumstances of Northern Ireland's ethno-national conflict and the constitutional settlement thereof. 68

The Commission continued outreach efforts in order to promote debate on its proposals. Based on these, a second and partially revised set of proposals was published in April 2004, entitled Progressing a Bill of Rights for Northern Ireland. ${ }^{69}$ These proposals were responsive to some of the criticisms of the Commission's earlier proposals, particularly with respect to the proposed rights to culture, identity and language. In the meantime, the Commission had also invited and received advice from the Organisation for Security and Cooperation in Europe's High Commissioner for National Minorities ${ }^{70}$ and from experts from the Council of Europe, ${ }^{71}$ although the interventions of these organisations attracted further controversy. ${ }^{72}$

Amidst the controversy around the Bill of Rights and the Human Rights Commission, the idea of a roundtable/forum, involving Northern Ireland's main political parties and various civil society groups was proposed to help build consensus and political support for the work of the Human Rights Commission. ${ }^{73}$ The UK and Irish governments endorsed that idea in their Joint Declaration of April 2003. ${ }^{74}$ Plans for a roundtable/forum remained stalled, however, while the Northern Ireland Assembly was suspended between 14 October 2002 and 7 May 2007. In the meantime, in February 2005, the Human Rights Commission produced a new progress report for incoming commissioners, Taking Forward a Bill of Rights for Northern Ireland, again with some revised proposals for the Bill of Rights. ${ }^{75}$ The document was written as a "briefing document" for the new Chief Commissioner and commissioners on progress thus far on the Bill. ${ }^{76}$

The St Andrews Agreement, reached in October 2006, cleared the way for the restoration of Northern Ireland's devolved government and the establishment of a Bill of Rights Forum. ${ }^{77}$ Consultation on the make-up and mandate of the forum was launched on 14

66 See C McCrudden, "Not the way forward” (2001) 52 NILQ 372, at 378-9; See also A Morgan, "What Bill of Rights" (2001) 52 NILQ 269.

67 McCrudden, "Not the way forward", n. 66 above, pp. 372-3.

68 Ibid. p. 377.

69 Progressing a Bill of Rights, n. 61 above.

70 Office of the OSCE HCNM, Note on the Possible Use of Terminology in the Process of Incorporating Into Domestic Law International Standards for the Protection of Minorities, 31 January 2003, www.nihrc.org/ index.php?option=com_content\&task=view\&id=53\&Itemid $=72$.

71 A W Heringa, G Malvinverni and J Marko, Comments by Council of Europe Experts on Certain Aspects of a Future Bill of Rights for Northern Ireland (Strasbourg: 3 February 2004), www.nihrc.org/ index.php?option=com_content\&task=view\&id $=53 \&$ Itemid $=72$.

72 See C McCrudden, "Consociationalism, equality, and minorities in the Northern Ireland Bill of Rights debate: the role of the OSCE High Commissioner on National Minorities", in J Morison, K McEvoy and G Anthony (eds), Judges, Transition, and Human Rights (Oxford: Oxford University Press 2007), pp. 342-52.

73 Professor Brice Dickson, the Chief Commissioner at the time and therefore in a position to know, suggests that the idea for the forum first emerged from the SDLP, see "Where now for the Bill of Rights?", Fortnight, February 2009, p. 11.

74 Joint Declaration by the British and Irish governments, April 2003.

75 Taking Forward a Bill of Rights for Northern Ireland, n. 57 above.

76 Professor Monica McWilliams took up the post of Chief Commissioner in September 2005.

77 Agreement at St Andrews, www.standrewsagreement.org/agreement.htm. 
November 2006. ${ }^{78}$ The forum itself was established on 12 December 2006, ${ }^{79}$ beginning its work on 18 December 2006. The forum consisted of 28 members, 14 from the main political parties of Northern Ireland (three each from the Democratic Unionist Party (DUP), Sinn Fein, Ulster Unionist Party (UUP) and SDLP, and two from the Alliance Party), and 14 representatives from a range of civil society organisations. ${ }^{80}$ The forum's inaugural meeting was held on 18 December 2006. Chris Sidoti, Director of the International Service for Human Rights, and a former Australian Human Rights Commissioner, was appointed as the independent Chair of the Bill of Rights Forum on 15 March 2007. Working groups were soon established in various areas to assist the forum in its deliberations. The forum met a total of 17 times, releasing its Final Report on 31 March 2008. ${ }^{81}$

The forum's report revealed persistent disagreement amongst the political parties and civil society groups. In nearly every area of rights protection, the report set out divergent and competing approaches, often echoing the disagreements that had previously beset the work of the Human Rights Commission. ${ }^{82}$ The DUP and the Catholic Church, although having participated throughout the forum's process, chose to boycott the release of the report in protest over the issue of reproductive rights. ${ }^{83}$ Clearly, the forum failed to build consensus as was hoped. The forum was helpful, however, in gauging support for the alternate proposals and clarifying the positions of the political parties and civil society groups. It might also be argued that the process itself was of value, particularly in bringing political parties and civil society together to discuss human rights. The work of the forum would provide a reference for the Human Rights Commission's subsequent work in formulating its advice on the Bill of Rights.

\section{The role of the Northern Ireland Human Rights Commission in finalising the Bill of Rights advice}

The establishment of a commission in Northern Ireland was reflective of broader international trends, as well as the dynamics of a peace process. An increasing number of national human rights institutions have emerged in recent times. ${ }^{84}$ Discussion continues on the nature and significance of these national institutions, and the existence of other such institutions has been a source of international advice and support for the Commission. The Commission is now only one of three such bodies in the UK, with the Scottish Human Rights Commission ${ }^{85}$ and the Equality and Human Rights Commission. ${ }^{86}$ The idea of a Bill

78 Northern Ireland Office, A Forum on a Bill of Rights for Northern Ireland: Consultation paper, 14 November 2006.

79 Northern Ireland Office, A Forum on a Bill of Rights for Northern Ireland: Response to consultation, 12 December 2006.

80 See Bill of Rights Forum, Final Report (Belfast: 31 March 2008).

81 Ibid.

82 There was consensus on technical provisions concerning the general limitations to rights (ibid., pp. 165-6), legal standing in relation to the Bill of Rights (ibid., pp. 172-3), legal remedies (ibid., p. 178), harmonisation with and non-diminution from the European Convention for the Protection of Human Rights and Fundamental Freedoms (ibid., p. 179), and government support for the implementation of the Bill of Rights (ibid., p. 186).

83 BBC, "Bill of rights blueprint launched", http://news.bbc.co.uk/1/hi/northern_ireland/7322501.stm.

84 See Bertrand G Ramcharan (ed), The Protection Role of National Human Rights Institutions (Leiden/Boston: Martinus Nijhoff Publishers 2005). See also the National Human Rights Institutions Forum's website, http://nhri.net/.

85 Established by the Scottish Commission for Human Rights Act 2006.

86 Established by the Equality Act 2006. 
of Rights is also no longer confined to Northern Ireland, and has resurfaced again in the British context, with discussions of a UK-wide Bill of Rights and Responsibilities. ${ }^{87}$

As noted, the Northern Ireland Human Rights Commission had the task of consulting and advising on a Bill of Rights. Even such general statements conceal the level of debate around this work. For example, whether the requirement to consult and advise on the "scope for defining" supplementary rights meant work on a Bill of Rights, and if it did, what was intended by that. Should the Commission draft a Bill of Rights? Should it recommend a concise range of additional rights only? What form might the "advice" take? Each element of the Commission's mandate was subjected to analysis, and the lack of consensus around its meaning suggested at the start the difficulties that would emerge later.

The landmark stages in the process have been mentioned up to the point of the handover of the forum's recommendations. It is worth focusing now on the final advice, submitted on 10 December 2008, and in particular the process followed to deliver it. ${ }^{88}$ In the final phase, much depended on the work of the Bill of Rights Forum. When the forum reported in March 2008, it was then for the Commission to take forward the next step. A decision was taken to set a deadline that would provide additional symbolism - the 60th anniversary of the Universal Declaration of Human Rights. In its submission to the Bill of Rights Forum, the Commission provided a hint of how it viewed the mandate. ${ }^{89}$ The submission acknowledged the need for a generous interpretation - and given the constitutional significance of its origins this was a defensible position. It was also recognised, however, that there were real limits to what could gain acceptance. The submission was significant for two reasons.

First, it confirmed that the Commission would be holding to the Agreement's mandate for the process, and regarded it as important to provide additional clarity on its meaning. There were other options. One option - which might be termed the "literalist" approach would be to advance a conservative and literal interpretation of the mandate, combined then with the use of the Commission's more general power to offer advice to government. ${ }^{90}$ The advantage of this approach would be to avoid potentially overloading the mandate with provisions its meaning could not accommodate. The disadvantage would be to neglect the "constitutional" significance of a generous interpretation, to accept a narrow reading of the mandate and erode the formal basis for the whole project. In the end, the Commission opted for the "constitutional and human rights" perspective, reading the mandate purposively and inclusively, but recognising the need to justify those rights included with reference to the Agreement's provisions. Although adopting this view - that the Agreement underpinned the advice - the Commission did, in its final document, include "additional recommendations to Government, not to be included in a Bill of Rights for Northern Ireland".91 Interpretative limits were acknowledged and it was accepted that elements which did emerge during the process could simply not be accommodated within even the most generous "constitutional" reading of the mandate.

87 Ministry of Justice, "Rights and responsibilities: developing our constitutional framework" Cm 7577 (Norwich: TSO March 2009). See also Joint Committee on Human Rights, "Twenty-ninth Report", n. 48 above.

88 Northern Ireland Human Rights Commission, A Bill of Rights for Northern Ireland: Advice to the Secretary of State (Belfast: NIHRC 2008).

89 Northern Ireland Human Rights Commission, Submission to the Round Table on a Bill of Rights for Northern Ireland (Belfast: NIHRC 2006).

90 Northern Ireland Act 1998, s. 69(7).

91 NIHRC, $A$ Bill of Rights, n. 88 above. 
Second, the Commission sought to outline how it interpreted and viewed the mandate. This signalled a desire to hold close to its prescribed task and attempt to explain the Commission's view of what was intended, a position which was more fully reflected in the final document.

This last point is confirmed when the methodology adopted by the Commission is examined. In June 2008, the Commission agreed a detailed methodology - in the form of guidelines - for discussing the final advice (the Commission had accepted the need for an overarching framework from 2001, when key principles to inform the process were adopted). The approach assisted the Commission in paying attention to the mandate, while also generating a discussion of justifications for the recommendations included. The guidelines start with "particular circumstances", move on to the legal aspects and the principles of mutual respect and parity of esteem, and also include a section on "the interests of the people of Northern Ireland". 92 The guidelines then go into more detail on how to deal with the particular circumstances of Northern Ireland, and an interpretation of "reflect the principles of mutual respect for the identity and ethos", described as "particular elements of the guidelines to which the Commission may have regard in its discussions". 93 This demonstrated an acute awareness of the need to be able to justify externally the approach adopted (it was generally well received), as well as providing guidance to commissioners facing the challenge of deciding which rights would merit inclusion. If this is considered alongside the scale of the process from 2000, it demonstrates the importance placed by the Commission, from its inception, on promoting a widespread and extensive debate.

The role of the Northern Ireland Human Rights Commission was established via the Belfast (Good Friday) Agreement, and the Northern Ireland Act 1998 refers expressly back to the relevant paragraph, making the connection clear. ${ }^{94}$ The St Andrews Agreement 2006, which was of significance in the restoration of devolution and in providing for the creation of the Bill of Rights Forum, did not alter the terms of the process. The two main process elements were to consult and to advise on the scope for defining potential rights. The Commission consulted widely during the eight-year process and the final advice has been submitted. Discussion continues on the adequacy of the consultation, as well as the content and substance of the final advice. The diversity of opinions involved has made the process an extensive and at times highly contested one. We now turn to how debates on rights relating to culture and identity have marked that process and why, in our opinion, the ultimate conclusions of the Commission on these rights embody a coherent and defensible approach to culture, identity, and the accommodation of minorities.

\section{Debating culture and identity in the Bill of Rights}

In an article published in the Critical Review of International Social and Political Philosophy in 2007, Professor Hadden observes that the approach to the protection of minorities in international human rights law and political practice tends to oscillate along a continuum, with individual rights on one end and the rights of communities on the other, creating a cyclical progression "rather like a pendulum". 95 As he explains, this "pendulum effect" is exhibited in the movement from the political philosophies of the American and French revolutions, which stressed the inalienable rights of the individual, through the nationalist and class-based politics of the 19th century and early 20th century, where communal

92 NIHRC, A Bill of Rights, n. 88 above, Appendix 1.

93 Ibid.

94 Northern Ireland Act 1998, s. 69(7).

95 T Hadden, "The pendulum theory of individual, communal and minority rights" (2000) 77 Critical Review of International Social and Political Philosophy 81. 
interests took centre stage, and then back again to an individualistic approach, with the Universal Declaration of Human Rights, following the Second World War. ${ }^{96}$ In the 1990s, the pendulum seemed to swing back again, with several international human rights documents focusing on the rights of groups. ${ }^{97}$

A similar pendulum effect can be observed in the debate on rights to culture, identity, and language throughout the latest phase of Northern Ireland's Bill of Rights process. Over the years, the Human Rights Commission and more recently the Bill of Rights Forum have advanced various proposals for rights pertaining to culture, identity, and language. As we will see, these proposals have oscillated between a "generic" and "individualistic" approach to minority rights, on the one hand, and what might be called a "targeted" or "groupdifferentiated" approach, on the other. ${ }^{98}$ According to the generic/individualistic approach, minority rights are ascribed to individuals and are equally accessible to all without any distinction based on membership in this or that group. Conversely, according to the targeted/group-differentiated approach, minority rights are differentiated with reference to the varying circumstances of different types of minorities. The central distinction in a group-differentiated approach is between "new" ethno-cultural minorities on the one hand, and "old" autochthonous or "national" minorities on the other, with different rights being ascribed according to the different types of claims and interests associated with these groups. ${ }^{99}$ Now, with the Human Rights Commission's latest advice on the Bill of Rights, the pendulum appears to have swung round in favour of a group-differentiated approach.

As he would likely concede, Professor Hadden's "pendulum theory" is a simplification of a more complex empirical reality. As with the evolution of minority rights in general, many of the proposals in the Bill of Rights debate are not purely individualistic or purely communitarian in character, but often combine aspects of both these paradigms. Indeed, it is a key feature of the group-differentiated approach that it allocates universal individual rights alongside rights that pertain only to certain groups. Moreover, Professor Hadden's description of the "pendulum effect" begs the question: what makes the pendulum move? It is our contention here, at least within the Bill of Rights debate, that the latest movement towards a more group-differentiated approach is driven by the strength of the better argument; the group-differentiated approach to minority rights really is the more desirable and intellectually coherent approach. The alternative rests on the false premise that minority interests are all essentially of the same kind, a view that is insensitive to the actual circumstances of different groups.

Rights to culture, identity and language were controversial from the outset of the latest phase in the Bill of Rights process. On the one hand, the Commission's mandate under the Belfast (Good Friday) Agreement explicitly stated that the Bill of Rights should "reflect the principles of mutual respect for the identity and ethos of both communities and parity of esteem". 100 This would suggest that such principles ought to inform the proposed Bill of Rights, perhaps as enforceable provisions in their own right. Furthermore, the emphasis on "both communities" here suggests a "group-differentiated" approach, where special rights

96 Hadden, "Pendulum theory", n. 95 above, p. 82.

97 As examples, Professor Hadden cites the International Labour Organisation's Convention 169 on Indigenous and Tribal peoples of 1989, the Copenhagen Document of the OSCE of 1990, the UN Declaration on the Rights of Persons Belonging to National or Ethnic Minorities of 1994 and the European Convention on the Protection of National Minorities of 1994. See ibid. p. 83.

98 The terminology here is borrowed from W Kymlicka, Multicultural Odysseys: Navigating the new international politics of diversity (Oxford: Oxford University Press 2007), p. 77.

99 See W Kymlicka, Multicultural Citizenship: A liberal theory of minority rights (Oxford: Clarendon Press 1995), ch. 3.

100 The Agreement, "Rights, safeguards, and equality of opportunity", para. 4. 
attach to the two main communities alongside whatever protections might apply to individuals or other minority groups. As was noted earlier, SACHR, of which Professor Hadden was a member, had previously suggested legislative or constitutional mechanisms along these lines. ${ }^{101}$ Professors Hadden and Boyle also seem to endorse such an approach in Northern Ireland: The Choice and in Ireland: A positive proposal; in the latter work a call is made for a Bill of Rights that would include both individual and communal rights. ${ }^{102}$ On the other hand, some (including some members of the Commission) have argued that the Bill of Rights should avoid further "entrenching" communal identity and should instead aim to vindicate "the rights of all on an equal basis". ${ }^{103}$ An underlying concern here is that the Agreement's focus on the "two communities" is flawed and risks reifying ethno-national difference at the expense of individuals who do not fit neatly into either communal box or may feel stronger connections to other "mixed" or "fluid" identities. ${ }^{104}$

For the most part, the Human Rights Commission's first consultation document, Making a Bill of Rights for Northern Ireland, adopted an individualistic and generic approach to minority rights. ${ }^{105}$ This approach was supported by the advice of the Culture and Identity Working Group (of which Professor Hadden was also a member), who had recommended that "[r]ights-bearers in the bill should be defined in individualistic terms", as "persons belonging to national, ethnic, religious, linguistic, cultural or other communities", and that " $t \mathrm{t}$ he bill should make clear that such rights-bearers are equal and are not confined to "both communities' but extend to persons belonging to a range of communities". ${ }^{106}$

In keeping with the working group's advice, the Commission's only proposal specifically targeted at persons belonging to the two main communities was a right of individuals born in Northern Ireland "to identify themselves and be accepted as Irish or British citizens, or both, as they may so choose". 107 This right effectively duplicates Article 1(vi) of the Agreement between the UK and the Republic of Ireland. ${ }^{108}$ It should also be noted that this provision understands national identity in terms of citizenship, as opposed to guaranteeing a more general right to parity of esteem or equality of treatment as between British and Irish national identities. Otherwise, the Commission's proposals followed a generic approach. Drawing on Article 27 of the ICCPR, the Commission proposed a provision guaranteeing that "[e]veryone belonging to a national, ethnic, religious or linguistic community shall have the right in common with other members of that

101 See SACHR, Second Report: Religious and political discrimination and equality of opportunity in Northern Ireland (Belfast: HMSO March 1990), ch. 8.

102 Boyle and Hadden, Northern Ireland: The Choice, n. 1 above; Boyle and Hadden, Ireland: A Positive Proposal, n. 1 above, p. 83 .

103 Northern Ireland Human Rights Commission, Making a Bill of Rights, n. 60 above, p. 19.

104 See Report of the Bill of Rights Culture and Identity Working Group, p. 1; see also Northern Ireland Human Rights Commission, Making a Bill of Rights, n. 60 above, p. 19; See also R Taylor, "Northern Ireland: consociation or social transformation?", in J McGarry (ed.), Northern Ireland and the Divided World (Oxford: Oxford University Press 2001), p. 45; see also R Wilson and R Wilford, "Northern Ireland: a route to stability?", p. 11, http://cain.ulst.ac.uk/dd/papers/dd03agreview.pdf. Worth noting in this general context is Professor Brendan O'Leary's reference to "Professor Hadden (and other liberal unionists) ...." in a discussion of the flying of flags. See J McGarry and B O'Leary, The Northern Ireland Conflict: Consociational engagements (Oxford: Oxford University Press 2004), p. 361.

105 Northern Ireland Human Rights Commission, Making a Bill of Rights, n. 60 above.

106 Report of the Bill of Rights Culture and Identity Working Group, p. 12.

107 Northern Ireland Human Rights Commission, Making a Bill of Rights, n. 60 above, cl. 1, p. 21.

108 The Agreement, "Constitutional issues", para. 1(vi). 
community to enjoy his or her own culture, to profess and practise his or her own religion and to use his or her own language". 109

The proposals also drew substantially from the Council of Europe's Framework Convention for the Protection of National Minorities. Largely inspired by Articles 4, 5, and 6 of the Framework Convention, the Commission proposed provisions requiring that, with respect to "persons belonging to national, ethnic, religious or linguistic communities", government and public bodies must promote equality in all areas, promote "the conditions necessary for them to maintain and develop their culture", and "preserve the essential elements of the identity of such persons, namely their religion, language, traditions and cultural heritage". ${ }^{110}$ In addition, government and public bodies would have a duty to "promote tolerance, mutual respect, understanding and co-operation among all persons living in Northern Ireland, irrespective of their cultural, ethnic, religious or linguistic identity, in particular in the fields of education, culture and the media". ${ }^{111}$

The Commission also drew upon Article 3(1) of the Framework Convention, proposing a right to self-identify (or not to identify) "as a member of what might otherwise be perceived to be their national, ethnic, religious or linguistic community and no disadvantage shall result from this choice or from the exercise of the rights which are connected to this choice". ${ }^{112}$ To assuage concerns that the right to self-identify might undermine Northern Ireland's equality monitoring measures (which allow a person's perceived communal background to be attributed to them where they refuse to identify as such), the Commission proposed a clause stating that the right could not be used "to negate equality commitments, including positive action provisions in the Bill of Rights or in legislation". 113

A minority within the Commission felt that this proviso was not enough, and, feeling that the Agreement's cross-community voting mechanisms were also potentially jeopardised, it recommended including an explicit statement that nothing in the above provisions could be used to "negate voting mechanisms designed to ensure representivity in political institutions and decision-making". 114 The minority also proposed, as an alternative, a clause requiring government and public bodies to "adopt effective and appropriate measures to ensure: mutual respect for all people in the diversity of their identities and traditions; and parity of esteem and just and equal treatment for the identity, ethos and aspirations of both communities". ${ }^{115}$ It added that the programmatic provisions of the Framework Convention on the Protection of National Minorities would be used as a "guide" to the implementation of that duty. 116

As was noted earlier, the Commission's first set of proposals on rights to culture, identity, and language attracted various criticisms. In light of these criticisms, the Commission's second consultation document, Progressing a Bill of Rights, proposed some important changes to the proposals concerning culture, identity, and language rights. ${ }^{117}$ First, the generic right to cultural enjoyment, religion and language was to apply to persons "belonging to a national, ethnic, religious or linguistic or cultural minority or

109 Northern Ireland Human Rights Commission, Making a Bill of Rights, n. 60 above, cl. 2, p. 23.

110 Ibid. cl. 5, p. 23.

111 Ibid. cl. 5(c), p. 23.

112 Ibid. cl. 4, p. 23.

113 Ibid. cl. 1, p. 23.

114 Ibid. p. 23.

115 Ibid. p. 24.

116 Ibid.

117 Northern Ireland Human Rights Commission, Progressing a Bill of Rights, n. 61 above. 
community". 118 The earlier proposal had only referred to "persons belonging to a national, ethnic, religious or linguistic community". As the Commission explained " $[\mathrm{t}]$ he terms 'minority' and 'community' have both been included in order to avoid any doubt that Catholics/nationalists/republicans or Protestants/unionists/loyalists would enjoy the rights in question". 119 Similarly, the use of the word "cultural" minority or community was intended to capture both unionism and nationalism, "even if they are not already deemed to be protected by the terms 'ethnic' or 'religious' minority or community". ${ }^{120}$

The Commission's second document also went further in proposing some "groupdifferentiated" provisions. While the new proposals did not include a specific right to "parity of esteem", they did include a clause requiring that the law in Northern Ireland "shall ensure just and equal treatment for the identities, ethos and aspirations of both main communities". 121 The Commission argued that "parity of esteem" was difficult to define, and that, in any case, the phrase "just and equal treatment" captured what was meant by "parity of esteem". ${ }^{122}$ It left the meaning of "identities, ethos, and aspirations" open, to be developed by case-law "if necessary". 123

In the area of language rights, the Commission's second consultation also proposed some "group-differentiated" provisions. There was no consensus on these, so three alternative approaches were laid out. The first approach would have granted equal status to both English and Irish as official languages in Northern Ireland. ${ }^{124}$ The second approach would have designated English as the "first official language" and Irish as the "second official language", leaving it to legislation to prescribe situations in which Irish could be used officially. 125 The third approach was a generic provision, simply stating that legislation would be adopted to "prescribe the situations in which people have the right to use the language of their choice". ${ }^{26}$ Section 14(4) of the proposals also provided for a programmatic duty to enact legislation to meet the commitments to the Irish and UlsterScots languages already made in the Belfast (Good Friday) Agreement and the European Charter on Regional and Minority Languages. ${ }^{127}$

The above proposals illustrate some movement in the thinking of the Commission towards a "group-differentiated" approach to minority rights. Nevertheless, the second set of proposals also retained (and arguably strengthened) some of the "individualistic" elements from the earlier proposals. In Making a Bill of Rights, the Commission had chosen to adapt Article 3(1) of the Framework Convention as a right to self-identify. That provision was accompanied, however, by a clause to protect equality monitoring schemes and positive action measures. In Progressing a Bill of Rights, the Commission chose instead to incorporate the Framework Convention on the Protection of National Minorities wholesale. ${ }^{128}$ The Commission explained that its intention was to make the whole of the convention enforceable in Northern Ireland. But this time the Commission's proposals omitted any limitations clause that would have insulated monitoring and positive action schemes from

118 Northern Ireland Human Rights Commission, Progressing a Bill of Rights, n. 61 above, s. 3(3), p. 30.

119 Ibid., p. 32.

120 Ibid.

121 Ibid. s. 3(2), p. 30.

122 Ibid. p. 32.

123 Ibid.

124 Ibid. s. 14(1), p. 67.

125 Ibid.

126 Ibid.

127 Ibid. s. 14(4), p. 68.

128 Ibid. s. 3(4), p. 30. 
challenge under Article 3(1) of the Framework Convention. The Commission stated that its understanding was that Article 3(1) would not render such schemes unlawful, but that it would merely give individuals the right "to insist that their chosen community affiliation will be recorded, as well as any perceived community background". 129

Despite the movement towards a "group-differentiated" approach seen in the Commission's second consultation document, the pendulum seemed to swing back towards a generic approach with the Bill of Rights Forum's Final Report. ${ }^{130}$ The report's proposals on culture, identity, and language were divided into two alternative options, reflecting lines of disagreement within the forum. Both options contained a generic right to enjoy one's culture, profess or practise one's religion, and use one's own language. ${ }^{131}$ Both options also included a right against "coercive cultural assimilation". ${ }^{132}$ Neither option provided for any rights that would apply specifically to the two main communities, except in the area of language rights, where both options proposed programmatic provisions for public authorities to promote indigenous minority languages. ${ }^{133}$ Option A also provided that persons belonging to a linguistic minority or community that is indigenous would have the right to be educated in and, where appropriate, through their language. ${ }^{134}$ Option B sought to give recognition to Irish and Ulster-Scots as indigenous languages by granting them "special status", in line with "the mutual respect for the identity and ethos of both communities and parity of esteem". 135

The Human Rights Commission's final advice pushes the pendulum back again towards a more "group-differentiated" approach. ${ }^{136}$ This is not to say that the latest proposals do not also retain many generic rights provisions. As we noted earlier, a group-differentiated approach has room for both generic and group-specific rights. Like the earlier reports, the latest proposals include a generic right of everyone belonging to a national, ethnic, religious, linguistic, or cultural minority to enjoy (individually or in community with other members of their group) their culture, profess or practise their religion, and to speak their own language in private or public. ${ }^{137}$ In addition, as in earlier proposals, the advice includes a duty upon public authorities to encourage a sprit of tolerance and dialogue and to promote mutual respect, understanding, and co-operation among all persons in Northern Ireland. ${ }^{138}$

The Commission's latest advice also retains a basically generic approach to language rights, in the sense that the rights apply without distinction to both indigenous and nonindigenous minority languages. ${ }^{139}$ The only aspect of the Commission's latest proposals to give special recognition to indigenous languages is the requirement that public authorities

129 Northern Ireland Human Rights Commission, Progressing a Bill of Rights, n. 61 above, p. 34.

130 Bill of Rights Forum, Final Report, n. 80 above.

131 Ibid. Option A, cl. 1, p. 67, and Option B, cl. 1, p. 68.

132 Ibid. Option A, cl. 3, p. 67, and Option B, cl. 5, p. 69.

133 Ibid. Option A, cl. 6, p. 67, and Option B, cl. 7, p. 69.

134 Ibid. Option A, cl. 5(a), p. 67.

135 Ibid. Option B, cl. 6, p. 69.

136 NIHRC, $A$ Bill of Rights, n. 88 above.

137 Ibid. cl. 4, p. 41.

138 Ibid. cl. 5 , p. 41.

139 The latest proposals provide for a right of "[e]veryone belonging to a linguistic minority has the right to learn or be educated in and through their minority language where there are substantial numbers of users and sufficient demand" (ibid. cl. 1, p. 42). The latest proposals also provide for a generic right "to access services essential to life, health or security through communication with a public authority, assisted by interpretation or other help where necessary, in a language (including sign language) and a medium that they understand" (ibid. cl. 2, p. 42). 
must "as a minimum, act compatibly with the obligations undertaken by the UK government under the European Charter for Regional or Minority Languages in respect of the support and development of Irish and Ulster-Scots". 140 While this does nothing to add to the substance of the obligations under the European Charter for Regional or Minority Languages, it does open up the possibility for the development of a local jurisprudence based on the charter but enforceable by domestic courts.

But alongside generic provisions, the Commission's latest proposals include rights that are specifically targeted at Northern Ireland's two main ethno-national groups. Like the earlier reports, the latest proposals include rights to identify as Irish or British or both and to hold either or both British and Irish citizenship, with no detriment or difference in treatment of any kind. ${ }^{141}$ The new proposals also include a right against being compelled to take an oath or "to take an oath in a manner" that is contrary to one's religion or belief, or that requires that one express a belief that one does not hold. ${ }^{142}$ Arguably the most "group-differentiated" feature of the Commission's latest proposals on minority rights is, as in the Commission's second consultation document, the inclusion of a duty upon public authorities to "fully respect, on the basis of equality of treatment, the identity and ethos of both main communities in Northern Ireland". 143 This last provision marks a clear movement back towards a "group-differentiated" approach, providing a broad basis for a rights-based jurisprudence specifically addressing the communal identities of "both main communities". Sensitivity to group dynamics in Northern Ireland is also reflected in other sections of the advice. For example, the sections on democratic rights make express reference to the safeguards under the Belfast (Good Friday) Agreement and recommend that equivalent protections be created for the new arrangements for local government. ${ }^{144}$ This recommendation on democratic rights relates directly to the particular circumstances of ethno-national division in Northern Ireland.

The final question to be addressed here is why this last movement in the pendulum, the shift back towards a more "group-differentiated" approach, is justified. The answer hinges on recognising that the circumstances of "national minorities" (understood here as autochthonous minorities whose members possess a distinct sense of political community $)^{145}$ are different in kind and cannot be adequately addressed under the rubric of generic minority rights. Because generic rights are intended to apply to all minorities they have to abstract from the specific circumstances of these groups. They cannot presume any specific substantive ends, since the substance of the aspirations of different groups (i.e. the degree of language rights, public recognition of political identity, group autonomy, and multicultural integration) will vary considerably between them. In other words, generic minority rights treat all individuals belonging to minorities as having essentially the same interests. Consequently, generic minority rights tend to be framed in negative terms, as rights against state interference with one's cultural enjoyment or the use

140 NIHRC, $A$ Bill of Rights, n. 88 above, cl. 3, p. 42.

141 Ibid. cll. 1 and 2, p. 41.

142 Ibid. cl. 6, p. 41.

143 Ibid. cl. 3, p. 41.

144 Ibid. cl. 4, p. 35: "A Bill of Rights for Northern Ireland recognises the safeguards contained in the Belfast (Good Friday) Agreement 1998 for inclusive, proportionate and equitable participation in regional government and recommends, by means to be determined in legislation, equivalent safeguards for local government."

145 On the distinctiveness of national minorities and the theory behind their constitutional accommodation, see generally S Tierney, Constitutional Law and National Pluralism (Oxford: Oxford University Press, 2004); see also F Requejo, Multinational Federalism and Value Pluralism (London: Routledge, 2005); and W Norman, Negotiating Nationalism: Nation-building, federalism, and secession in the multinational state (Oxford: Oxford University Press 2006). 
of one's own language. ${ }^{146}$ Where there are positive obligations imposed on the state, these tend to be framed in a vague and programmatic style, as in a general duty to promote multiculturalism or tolerance. ${ }^{147}$

As Will Kymlicka has argued, rights to cultural enjoyment and programmatic duties to promote multiculturalism might be appropriate to the circumstances of "small and halfassimilated minorities", allowing them "to negotiate their integration into the dominant society with a certain amount of dignity and security". ${ }^{48}$ However, these measures do little to address the distinctive concerns of national minorities. ${ }^{149}$ In the case of national minorities, the sense of having long-standing ties to a given territory and a distinct sense of political community gives rise to special types of claims. ${ }^{150}$ One such claim is the claim to self-determination. With the Belfast (Good Friday) Agreement this issue has now been cast within an agreed constitutional framework, requiring that the governments of the United Kingdom and the Republic of Ireland give effect to the "right of self-determination on the basis of consent" of the people of the island of Ireland as a whole, subject to "the agreement and consent of a majority of the people of Northern Ireland". ${ }^{151}$

But another type of claim arising from the circumstances of national minorities is the claim for equal recognition in the public sphere. The modern state inevitably promotes some construction of collective identity at the expense of other constructions. As Margaret Moore puts it, "state policies, and state boundaries, are necessarily implicated in the recognition (or non-recognition) and reproduction of national groups". ${ }^{152}$ Thus, even where there is no discrimination, difference-blind laws and policies can often favour statecentred identities by default. ${ }^{153}$ As such, a just and pluralistic public sphere, one in which multiple national identities can peacefully co-exist on fair terms, may require positive schemes of accommodation and recognition with respect to sub-state national identities. This means accommodating national identities in a "group-differentiated" way, doing justice to their distinctive interests alongside those of other ethno-cultural groups.

The parties to the Agreement appear to have recognised this last point in providing that, regardless of which government holds sovereignty over Northern Ireland, public power "shall be exercised with rigorous impartiality", founded, inter alia, on the principles of "parity of esteem and of just and equal treatment for the identity, ethos, and aspirations of both communities". 154 So far, however, the approach to the accommodation of culture,

146 See e.g. Article 27 of the UN's International Covenant on Civil and Political Rights.

147 See e.g. Article 6(1) of the Council of Europe's Framework Convention for the Protection of National Minorities, Strasbourg, 1.II.1995.

148 Kymlicka, Multicultural Odysseys, n. 98 above, p. 214.

149 Ibid., p. 216.

150 For example, Kymlicka argues: "All else being equal, national minorities should have the same tools of nationbuilding available to them as the majority nation, subject to the same liberal limitations. What we need, in other words, is a consistent theory of permissible forms of nation-building within liberal democracies." W Kymlicka, Politics in the Vernacular: Nationalism, multiculturalism and citizenship (Oxford: Oxford University Press 2001), p. 29.

151 The Agreement, "Constitutional issues", para. 1.

152 M Moore, The Ethics of Nationalism (Oxford: Oxford University Press 2000), p. 18; see also Kymlicka, Multicultural Citizenship, n. 99 above, p. 108.

153 See S O’Neill, “Justice in ethnically diverse societies” (2003) 3 Ethnicities 369.

154 The Agreement, "Constitutional issues”, para. 1(v). 
identity, and language in Northern Ireland has been piece-meal, with various and sometimes contradictory strategies being scattered across a range of legislative instruments, judicial rule-making, and government policies. ${ }^{155}$

One of the potential benefits of a Bill of Rights for Northern Ireland then would be its capacity to help bring some coherence and unity to otherwise disparate approaches to culture, identity, and language. This would be the point of including a right to "just and equal treatment for the identity, ethos and aspirations of both communities". On the symbolic level, this would provide recognition that the accommodation of the Irish/nationalist/republican community in Northern Ireland cannot simply be subsumed under the generic minority rights paradigm. More significantly, however, the right would provide a mechanism to correct imbalances in the way public bodies are either repressive or expressive of national identity in their dealings with people.

\section{Conclusion}

In this article we have used the example of the Bill of Rights process in Northern Ireland to stress the importance of context. Such constitutional measures should draw upon international instruments and experience, but they also need to be crafted in ways that acknowledge the particular circumstances of the society within which they must operate. A Bill of Rights that fails to pay attention to national and local contexts may struggle to gain the grounding needed to function effectively. Any Bill of Rights process which genuinely attempts to produce proposals with this in mind will inevitably provoke disagreement and debate, precisely because it will be facing into societal controversy rather than seeking to avoid it.

We have drawn on the example of the final advice of the Northern Ireland Human Rights Commission to suggest that it is possible to do this in a reasonably coherent and defensible way. In our view, a Bill of Rights can address the main particular circumstance in Northern Ireland - ethno-national division - in ways that accord fully with persuasive modern understandings of culture and identity and which do not hamper the desire to promote full respect for human rights. While we do not expect Professor Hadden to agree with all of our arguments here, we do hope to have persuaded him (and others) that the "pendulum" has indeed swung back again in the right direction.

155 For a helpful overview of some of these strategies see D Bryan and G McIntosh, "Symbols and identity in the 'New' Northern Ireland" in P Carmichael, C Knox, and R Osborne (eds), Devolution and Constitutional Change in Northern Ireland (Manchester: Manchester University Press 2007), pp. 125-37. 
